\title{
Effect of Storage Life of Rice Bran on the Quality of Oil
}

\author{
Sharmin Akter ${ }^{1}$, Md Ahiduzzaman ${ }^{2}$ \\ ${ }^{1}$ Food Technology and Nutritional Science of Mawlana Bhashani Science and Technology University, Tangail, Bangladesh \\ ${ }^{2}$ Department of Agro-Processing, Bangabandhu Sheikh Mujibur Rahman Agricultural University, Gazipur, Bangladesh
}

Email address:

shaakter88@gmail.com (S. Akter), ahid72@yahoo.com (M. Ahiduzzaman)

To cite this article:

Sharmin Akter, Md. Ahiduzzaman. Effect of Storage Life of Rice Bran on the Quality of Oil. Journal of Food and Nutrition Sciences. Vol. 5, No. 1, 2017, pp. 11-15. doi: 10.11648/j.jfns.20170501.12

Received: October 23, 2016; Accepted: December 26, 2016; Published: March 2, 2017

\begin{abstract}
Rice is one of the staple food in Bangladesh. The most important milling by-product of rice is 'rice bran' which is an excellent source of edible oil. Due to the poor storage facility in the rice milling industry, the quality of rice bran gets deteriorates rapidly. This study examines the deterioration level of rice bran during the storage period in average room temperature $\left(31^{\circ} \mathrm{C}\right)$. Raw, partially parboiled and parboiled rice bran was collected right after milling. Oil is extracted by 'hexane solvent extraction' method from the 1st day of storage period for one week with the interval. Free fatty acid level, lipase activity, Iodine value and the $\mathrm{pH}$ value was determined from the collected rice bran oil. The preliminary result of this study showed that the deterioration level is rapidly increased during the 1 week of storage and the maximum deterioration level was found in raw rice bran. The free fatty acid (FFA) level, the degree of unsaturation and $\mathrm{pH}$ was respectively $17.25 \%, 92 \mathrm{~g}$ Iodine $/ 100 \mathrm{ml}$ oil and 3.10 , whereas in parboiled rice bran it was respectively $4.23 \%, 101.1 \mathrm{~g}$ Iodine $/ 100 \mathrm{ml}$ oil and 6.23 . Since the parboiled rice bran undergoes through a traditional stabilization method of parboiling and drying before milling, it might be a reason for the lower level of deterioration. The oil collected right after milling also showed a lower lipase activity. This study can be concluded by considering that, the less the storage time the better is the quality of the oil.
\end{abstract}

Keywords: Rice Bran, Oil, Storage Life of Oil, Free Fatty Acid

\section{Introduction}

Rice bran, which includes the pericarp, the aleurone and sub-aleurone layers, parts of the germ and the embryo as well as small portions of the starchy endosperm $[1,2]$, is a major co-product of rice milling process accounting for $5-8 \%$ of milled rice [3]. Bran, $10 \%$ of the weight of rough rice, is rich in oil (15-22\%), depending on the milling procedure and the rice variety $[1,4]$. Raw rice bran contains active lipolytic enzymes- lipases, which hydrolyses the triglycerides and releases free fatty acid from the rice bran. The lypolytic action of the enzymes is responsible for the deterioration of the rice bran and oil during storage, as the cause rancidity due to the increase of FFA [5].

Rapid increase in the free fatty acid occurs within hours and reaches $7-8 \%$ within 24 hours, followed by about $5 \%$ increase per day $[6,7]$. Lipase activity is enormously affected by different kind of relative factors such as moisture, temperature, $\mathrm{pH}$, time and water activity [8-10].

This paper presented data on the lipase activity of rice bran due to free fatty acid content, degree of unsaturation and $\mathrm{pH}$ level of three different types of rice bran following storage period. These three type of rice bran differentiate based on their milling procedure such as raw rice bran, partially parboiled rice bran and parboiled rice bran. Bran collected soon after milling and stored at room temperature for 1 week period. Rice bran oil is extracted from each type of bran during the storage period and free fatty acid value, iodine value, and $\mathrm{pH}$ were examined to provide a varied comparison of quality deterioration during storage. The goal of this study was to determine the quality changes of different type of locally available rice bran during the storage period.

\section{Materials and Method}

\subsection{Reagents}

n-hexane 95\% pure (Merck, Germany), iso-propyl alcohol (Sigma-Aldrich Co.), sodium hydroxide, sodium thiosulphate and starch (Merck, Germany), phenolepthaliene (Ajax Chemical Co.), Iodine Monochloride reagent (Sigma-Aldrich 
Co.), potassium iodide and chloroform (Merck, Germany).

\subsection{Rice Bran Sample}

Three different type of rice bran were collected i.e. Parboiled rice bran, partially parboiled rice bran and raw or un-parboiled rice bran. Fresh sample was collected from different auto rice mills located in Bangladesh. Parboiled rice bran was collected from auto rice mill located in Bilashpur, Gazipur. Partial parboiled rice bran was collected from Madina auto rice mill located in Tangail, and Un-parboiled rice bran was collected from BRRI (Bangladesh Rice Research Institute)

\subsection{Rice Bran Oil Extraction}

$100 \mathrm{gm}$ rice bran sample added with $95 \%$ pure $\mathrm{n}$-hexane at a ratio 4:1 (ml hexane: rice bran). After 8-9 hours of steeping, liquid hexane solution filtered from bran. Hexane solvent mixed with the fat and the defatted bran is separated. Oil is extracted from the solvent by soxhlet apparatus. The solvent evaporated $\left(\right.$ at $\left.60^{\circ} \mathrm{C}\right)$ and pass through the condenser which then collected from the syphon for further use. The oil is collected when there is no more hexane available in the bottom.

\subsection{Free Fatty Acid (FFA) \% Determination for Lipase Activity}

Lipase activity was determined by estimating the amount of free fatty acids (FFA) in rice bran on daily basis up to 7 days (AOAC 940.28). 1 gram of catalyst (lye or $\mathrm{KOH}$ ) mixed with $1000 \mathrm{ml}$ of water to make $0.1 \%$ solution. To perform a blank titration $10 \mathrm{ml}$ isopropyl alcohol mixed with 2-3 drop phenolphthalein indicator in a beaker. Lye/water added drop by drop with continuous stirring. The moment it turned purple, starting point of titration was marked. Now this process was repeated with the oil sample. Exactly $1 \mathrm{ml}$ of oil sample is taken, and titration performed.

\subsection{Degree of Unsaturation in Rice Bran Oil}

The degree of unsaturation of crude rice bran oil was determined by an analytical method of Iodine value (AOAC 920.158), which provides the saturation and unsaturation of crude rice bran oil.

$10 \mathrm{ml}$ of fat sample was dissolved in chloroform which is then mixed thoroughly with $20 \mathrm{ml}$ of iodine monochloride reagent at an iodination flask labeled 'test' and kept half an hour incubation in dark. Made a blank sample by adding $10 \mathrm{ml}$ chloroform with $20 \mathrm{ml}$ iodine monochloride and allowed to stand for 30 minutes in incubator at dark. After 30 minutes of incubation, the test sample was taken out and mixed with $10 \mathrm{ml}$ of potassium iodide. Then this sample is titrated against standardized sodium thiosulfate until a pale straw color observed. Then about $1 \mathrm{ml}$ starch indicator added, and the solution turned purple. Titration continued until the sample solution turned colorless and the titration point noted. The same procedure performed for the blank sample solution and endpoint noted. The $\mathrm{pH}$ value was measured by Hach $\mathrm{pH}$ meter.

\section{Result and Discussion}

\subsection{Oil Yield from Rice Bran Sample}

Maximum oil content (20\% approximate) was found from parboiled rice bran. Oil found from this solvent extraction method are crude oil, thus it may contain different types of impurities such as gums and waxes. Partially parboiled-rice bran yields a little less than full parboiled rice bran. No doubt, the yield of parboiled oil was more but the main hurdle is its dark color that is undesirable. In this relation, Amarasinghe and Gangodavilage [9], reported that the parboiled rice bran has approximately $20-26 \%$ greater oil content than raw rice bran.

Table 1. Approximate crude oil yield from different type of rice bran.

\begin{tabular}{ll}
\hline Rice Bran Sample & Average Oil Yield (\%) Approximate \\
\hline Parboiled & $20 \mathrm{ml}$ \\
Partially Parboiled & $18.5 \mathrm{ml}$ \\
Un-parboiled & $17 \mathrm{ml}$ \\
\hline
\end{tabular}

\subsection{Lipase Activity of Crude Rice Bran Oil}

Rice bran contains lipases, primarily responsible for the hydrolysis of triglycerides into glycerol and free fatty acids; further oxidized by peroxidases, provoking bran's rancidity. The highest FFA level (Table 2) was observed in unparboiled rice bran $(7.05 \%$ after 12 hours) followed by partially parboiled rice bran $(8.46 \%$ after 2 days), and Parboiled rice bran $(3.17 \%$ after 2 days); however, the minimum value $3.17 \%$ was observed in full parboiled rice bran sample collected from Bilashpur even after 48 hours of storage time. After stabilization, there was less formation of FFA in all stabilized bran samples. These results are in the same trend of those reported elsewhere $[9,11]$.

After stabilization, there was less formation of FFA in all Parboiled bran samples. Nevertheless, there was a gradual increase in FFA level in all bran samples during 1 week of storage due to residual lipolytic activity that increased under favorable conditions. After the $1^{\text {st }}$ day of storage, the minimum FFA level of parboiled rice bran was $3.17 \%$ which gradually increased to $4.23 \%$ after 1 week of storage, respectively. Consequently, the minimum FFA level of partially parboiled rice was $8.46 \%$ after 2 days of storage which gradually increased to $13.25 \%$ and The FFA level of un-parboiled rice bran was $7.05 \%$ after 12 hours of milling and gradually increased to $17.25 \%$ after 1 week of storage.

However, the maximum increase was observed in unparboiled rice bran. Hydrolysis of triglycerides forms free fatty acids, the principal cause of deterioration occurring rapidly during the first few days or weeks after milling [6, 12]. After bran separation, the oil is exposed to lipases, causing its rapid breakdown to free fatty acids [13]. Lipase activity results in significant increase in free fatty acid concentration and reaches 7 to $8 \%$ within 24 hours and then subsequently increases by 4 to $5 \%$ per day up to $70 \%$ FFA has been reported for a single month storage $[14,15]$. Rice bran having more than $15 \%$ FFA becomes rancid [16]. Free fatty acids concentration in rice bran is dependent on the 
changes in temperature and moisture content experienced, by the bran during storage [17]. The nutritional quality and palatability of rice bran deteriorate rapidly as the oil undergoes hydrolytic and oxidative rancidity [18].

Table 2. FFA content of different types of rice bran oil during storage period.

\begin{tabular}{|c|c|c|c|c|c|c|c|c|}
\hline \multicolumn{3}{|c|}{ Parboiled rice bran } & \multicolumn{3}{|c|}{ Partially parboiled rice bran } & \multicolumn{3}{|c|}{ Un-parboiled rice bran } \\
\hline Sample name & $\begin{array}{l}\text { Storage } \\
\text { period (day) }\end{array}$ & $\begin{array}{l}\text { FFA \% as } \\
\text { Oleic Acid } \\
\end{array}$ & $\begin{array}{l}\text { Sample } \\
\text { name }\end{array}$ & $\begin{array}{l}\text { Storage } \\
\text { period (day) }\end{array}$ & $\begin{array}{l}\text { FFA \% as } \\
\text { Oleic Acid } \\
\end{array}$ & $\begin{array}{l}\text { Sample } \\
\text { name }\end{array}$ & $\begin{array}{l}\text { Storage } \\
\text { period (day) }\end{array}$ & $\begin{array}{l}\text { FFA \% as } \\
\text { Oleic Acid }\end{array}$ \\
\hline Bil-1 & 2 & 3.17 & Tan-1 & 2 & 8.46 & BRRI-1 & 12 hour & 7.05 \\
\hline Bil-2 & 3 & 3.87 & Tan-2 & 3 & 10.4 & BRRI-2 & 1 & 9.87 \\
\hline Bil-3 & 4 & 3.9 & Tan-3 & 4 & 11.28 & BRRI-3 & 2 & 14.8 \\
\hline Bil-4 & 5 & 4.159 & Tan-4 & 5 & 12.1 & BRRI-4 & 3 & 16.5 \\
\hline Bil-5 & 6 & 4.23 & Tan-5 & 6 & 13.25 & BRRI-5 & 4 & 17.25 \\
\hline
\end{tabular}

\subsection{Iodine Value of Crude Rice Bran Oil}

The Iodine value for the parboiled rice bran oil in this study was found to be $102.1 \mathrm{~g} \mathrm{I}_{2} / 100 \mathrm{~g}$ oil (Table 3 ). This value is decreased to $101.87,101.6$, and 101.52 respectively during 1 week of storage. The level of unsaturation could have been greater than the obtained value if it was refined before measurement. The progressive reduction in Iodine value usually could be attributed to lipid oxidation [19].

The Iodine value for the crude rice bran oil yield from partially parboiled rice bran oil is less than the value found from full parboiled rice bran oil. The degree of unsaturation of crude rice bran oil from partially parboiled rice bran was found to be $100.8 \mathrm{~g} \mathrm{I}_{2} / 100 \mathrm{~g}$ oil (Table 3) during 2 days of storage. This value is decreased to $100.2,99.8,98.98$ and 97.7 respectively during 1 week of storage.

The Iodine value for the crude rice bran oil yield from unparboiled rice bran oil is lesser than the value found from full parboiled rice bran oil. These may be caused because of the un-stabilization of the rice bran. The degree of unsaturation of crude rice bran oil from raw rice bran was found to be 93.9g $I_{2} / 100 \mathrm{~g}$ oil (Table 3 ) during 12 hours of storage period. This value is decreased to $93.27,92.63$ and 92.0 respectively during 1 week of storage period.

Table 3. Iodine value of different type of crude rice bran oil.

\begin{tabular}{|c|c|c|c|c|c|c|c|c|}
\hline \multicolumn{3}{|c|}{ Parboiled rice bran oil } & \multicolumn{3}{|c|}{ Partially parboiled rice bran oil } & \multicolumn{3}{|c|}{ Un-parboiled rice bran oil } \\
\hline Sample name & Storage time & Iodine value & Sample name & Storage time & Iodine value & Sample name & Storage time & Iodine value \\
\hline Bil-1 & 2 Day & 102.1 & Tan-1 & 2 Day & 100.8 & BRRI-1 & 12 hour & 93.9 \\
\hline Bil-2 & 3 Day & 101.87 & Tan-2 & 3 Day & 100.2 & BRRI-2 & 1 Day & 93.27 \\
\hline Bil-3 & 4 Day & 101.6 & Tan-3 & 4 Day & 99.8 & BRRI-3 & 2 Day & 92.63 \\
\hline \multirow[t]{2}{*}{ Bil-4 } & 5 Day & 101.52 & Tan-4 & 5 Day & 98.98 & BRRI-4 & 4 Day & 92.0 \\
\hline & & & Tan-5 & 6 Day & 97.7 & & & \\
\hline
\end{tabular}

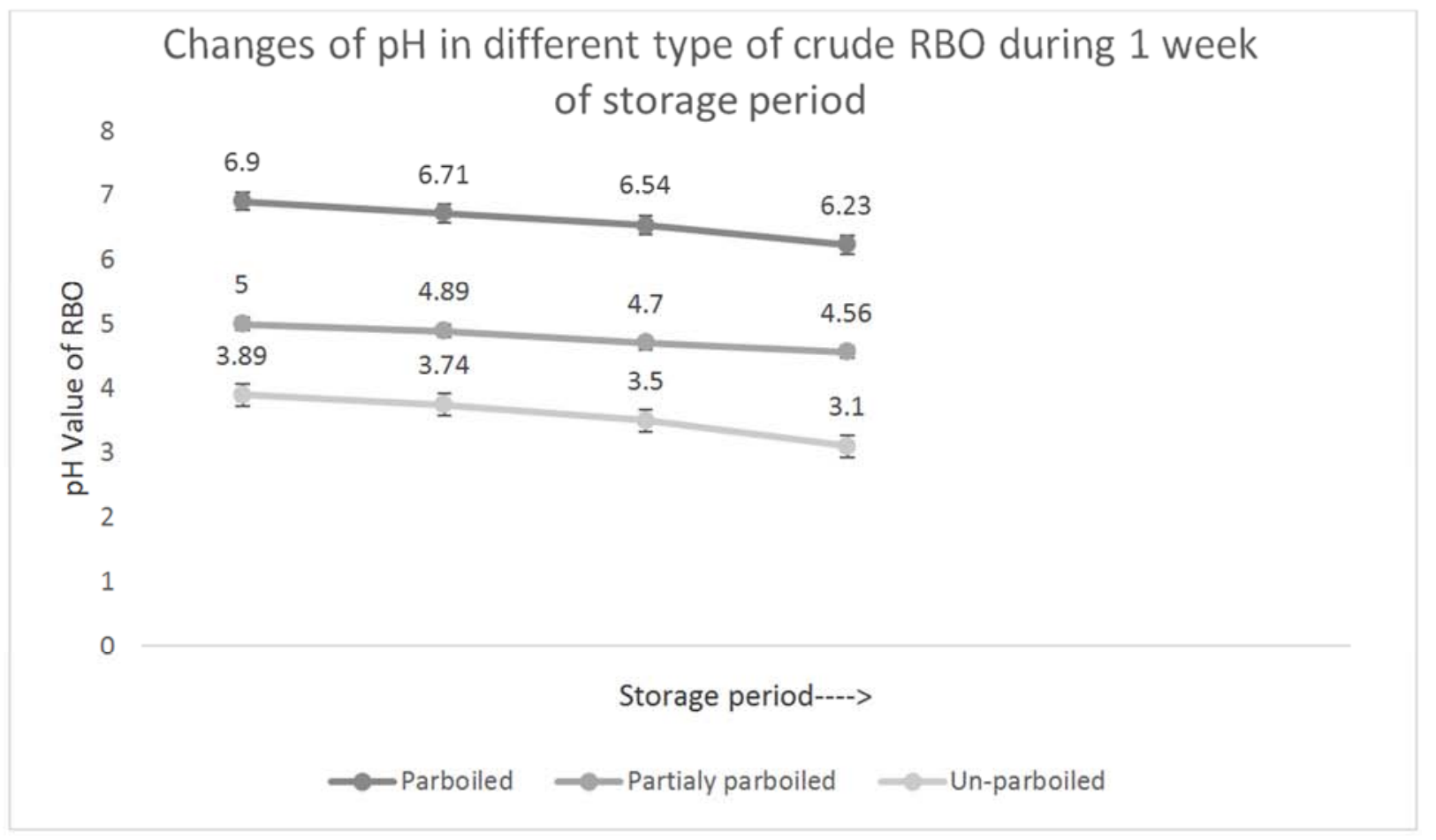

Figure 1. pH Value of Different Type of Crude Rice Bran Oil. 


\section{4. pH Value of Crude Rice Bran Oil}

$\mathrm{pH}$ value of different type of crude rice bran oil is determined by using a $\mathrm{pH}$ meter. Fully parboiled rice bran oil has shown nearly neutral $\mathrm{pH}$ level which is 6.9 after minimum days of storage. And the minimum level of $\mathrm{pH}$ has found on the un-parboiled rice bran oil which is 3.10 after one week of storage. Several studies have conducted on the stabilization of rice bran oil, by maintaining different criteria, but a new stabilization method has reported that controlling the $\mathrm{pH}$ level of the rice bran oil can minimize the lipase activity of the rice bran oil for longer period of storage, where lipase activity of rice bran oil is increasing during storage, while the $\mathrm{pH}$ value is decreasing [20].

\subsection{Comparison Study of pH Value with FFA Content (\%) Level of Crude Rice Bran Oil}

$\mathrm{pH}$ value of crude rice bran oil shows a gradual decrease during storage in this study which has been mentioned earlier (figure 1). The FFA level of rice bran oil is gradually increasing during the storage period (Table 4). By evaluating these data from the storage study of rice bran, there is a significant relation found on $\mathrm{pH}$ value and FFA content of crude rice bran oil. The lower the $\mathrm{pH}$ value of crude rice bran oil, the higher the FFA content.

Table 4. Changes in pH in relation with FFA content (\%) of crude RBO.

\begin{tabular}{|c|c|c|c|c|c|c|c|c|}
\hline \multicolumn{3}{|c|}{ Parboiled rice bran oil } & \multicolumn{3}{|c|}{ Partially parboiled rice bran oil } & \multicolumn{3}{|c|}{ Un-parboiled rice bran oil } \\
\hline $\begin{array}{l}\text { Sample name } \\
\text { (storage period } \\
\text { in day) }\end{array}$ & $\begin{array}{l}\text { pH Value } \\
( \pm 0.01)\end{array}$ & $\begin{array}{l}\text { FFA content } \\
(\%)\end{array}$ & $\begin{array}{l}\text { Sample name } \\
\text { (storage period } \\
\text { in day) }\end{array}$ & $\begin{array}{l}\text { pH Value } \\
( \pm 0.01)\end{array}$ & $\begin{array}{l}\text { FFA } \\
\text { content (\%) }\end{array}$ & $\begin{array}{l}\text { Sample name } \\
\text { (storage period } \\
\text { in day) }\end{array}$ & $\begin{array}{l}\text { pH Value } \\
( \pm 0.01)\end{array}$ & $\begin{array}{l}\text { FFA content } \\
(\%)\end{array}$ \\
\hline Bil-1 (2) & 6.9 & 3.17 & Tan-1 (2) & 5.00 & 8.46 & BRRI-1 (12 & 3.89 & 7.05 \\
\hline Bil-2 (3) & 6.71 & 3.87 & Tan-2 (3) & 4.89 & 10.4 & hour's) & 3.74 & 9.87 \\
\hline Bil-3 (4) & 6.54 & 4.159 & Tan-3 (4) & 4.7 & 11.28 & BRRI-2 (1) & 3.5 & 14.8 \\
\hline Bil-4 (5) & 6.23 & 4.23 & Tan-4 (5) & 4.56 & 12.1 & BRRI-3 (2) & 3.10 & 17.25 \\
\hline & & & Tan-5 (6) & 4.52 & 13.25 & BRRI-4 (4) & & \\
\hline
\end{tabular}

\section{Conclusion}

Rice bran oil is one of the most important source of edible oil. Storage of rice bran oil before oil extraction is an important factor on the qualit of final oil. During storage of rice bran in room temperature $\left(37^{\circ} \mathrm{C}\right)$ the FFA (Free fatty acid) content increase rapidly and deteriorate the quality of rice bran. The raw rice bran showed higher free fatty acid level and lower Iodine value whether the partially parboiled and parboiled rice showed less quality deterioration respectively. Fully parboiled rice bran shows FFA content which was $3.17 \%$, maximum degree of unsaturation $(102.1 \mathrm{~g}$ Iodine $/ 100 \mathrm{ml}$ oil) and nearly neutral $\mathrm{pH}$ level. FFA level of raw rice bran is found to be increasing during storage time which was up to $17.25 \%$ after one week of storage. Fully parboiled-rice bran which was collected and processed soon after the milling process showed minimum lipase activity and quality deterioration during storage period.

\section{References}

[1] Houston, D. F., Rice: Chemistry and Technology, American Association of Cereal Chemists, 1972.

[2] Saunders, R., The properties of rice bran as a foodstuff. Cereal Foods World. Vol. 35, No. 7, pp. 632, 634-636, 1990.

[3] Sereewatthanawut, I., S. Prapintip, K. Watchiraruji, M. Goto, M. Sasaki, and A. Shotipruk, Extraction of protein and amino acids from deoiled rice bran by subcritical water hydrolysis. Bioresource technology. Vol. 99, No. 3, pp. 555-561, 2008.

[4] Martin, E. and D. Farrell, Strategies to improve the nutritive value of rice bran in poultry diets. II. Changes in oil digestibility, metabolisable energy and attempts to increase the digestibility of the oil fraction in the diets of chickens and ducklings. British poultry science. Vol. 39, No. 4, pp. 555$559,1998$.

[5] Zainuddin, Z., Quality characteristics of rice bran oil and the utilization of rice bran from selected Malaysian rice varieties, Thesis Universiti Pertanian Malaysia, 1990.

[6] Ramezanzadeh, F. M., R. M. Rao, M. Windhauser, W. Prinyawiwatkul, and W. E. Marshall, Prevention of oxidative rancidity in rice bran during storage. Journal of agricultural and food chemistry. Vol. 47, No. 8, pp. 2997-3000, 1999.

[7] Rukmini, C. and T. C. Raghuram, Nutritional and biochemical aspects of the hypolipidemic action of rice bran oil: a review. Journal of the American College of Nutrition. Vol. 10, No. 6, pp. 593-601, 1991.

[8] Dunford, N. T. and J. W. King, Thermal gradient deacidification of crude rice bran oil utilizing supercritical carbon dioxide. Journal of the American Oil Chemists' Society. Vol. 78, No. 2, pp. 121-125, 2001.

[9] Amarasinghe, B. and N. Gangodavilage, Rice bran oil extraction in Sri Lanka: Data for process equipment design. Food and bioproducts processing. Vol. 82, No. 1, pp. 54-59, 2004.

[10] Amarasinghe, B., M. Kumarasiri, and N. Gangodavilage, Effect of method of stabilization on aqueous extraction of rice bran oil. Food and Bioproducts Processing. Vol. 87, No. 2, pp. 108-114, 2009.

[11] Thanonkaew, A., S. Wongyai, D. J. McClements, and E. A. Decker, Effect of stabilization of rice bran by domestic heating on mechanical extraction yield, quality, and antioxidant properties of cold-pressed rice bran oil (Oryza saltiva L.). LWT-Food Science and Technology. Vol. 48, No. 2, pp. 231-236, 2012. 
[12] da Silva, M. A., C. Sanches, and E. R. Amante, Prevention of hydrolytic rancidity in rice bran. Journal of Food Engineering. Vol. 75, No. 4, pp. 487-491, 2006.

[13] Desikachar, H. Preservation of by-products of rice milling. in Proc: Rice By-products Utilization Int. Conf., Valencia, Spain, 1974.

[14] Orthoefer, F. T., Rice bran oil. Bailey's industrial oil and fat products. Vol., 2005.

[15] Orthoefer, F. T., Rice bran oil: healthy lipid source. Food Technology. Vol. 50, No. 12, pp. 62-64, 1996.

[16] Tai-Sun, S. and J. S. Godber, Isolation of four tocopherols and four tocotrienols from a variety of natural sources by semipreparative high-performance liquid chromatography. Journal of Chromatography A. Vol. 678, No. 1, pp. 49-58, 1994.
[17] Fernando, W. and L. Hewavitharana, Effect of fluidized bed drying on stabilization of rice bran. Drying Technology. Vol. 11, No. 5, pp. 1115-1125, 1993.

[18] Tsai, Y. and C. Huang, Effect of the antitryptic activity of rice bran on growth, feed efficiency and residual tryptic activity in the intestinal content and feces of the rat. Chung-kuo nung yeh hua hsueh hui chih= Journal of the Chinese Agricultural Chemical Society. Vol., 1982.

[19] Chan HWS, C. D., The mechanism of autoxidation. Academic Press, Inc., Orland. Fla. P. 49. Vol., 1987.

[20] Prabhakar, J. and K. Venkatesh, A simple chemical method for stabilization of rice bran. Journal of the American Oil Chemists Society. Vol. 63, No. 5, pp. 644-646, 1986. 